Civil Engineering

Volume 171 Issue CE5

Subsea road tunnels in the Faroe Islands Samuelsen and Grøv
Proceedings of the Institution of Civil Engineers Civil Engineering 171 May 2018 Issue CE5 Pages 25-30 https://doi.org/10.1680/jcien.17.00032 Paper 1700032

Received 07/07/2017

Published online 15/01/2018

Keywords: geotechnical engineering; infrastructure planning; tunnels \& tunnelling

(C) Published with permission by the ICE under the CC-BY 4.0 license. (http://creativecommons.org/licenses/by/4.0/)

\title{
Sulbsea road tunnels in the Faroe Islands
}

1 Teitur Samuelsen

Managing Director, P/F Eystur- og Sandoyartunlar, Faroe Islands
2 Eivind Grøv

Professor, Sintef/NTNU, Norway
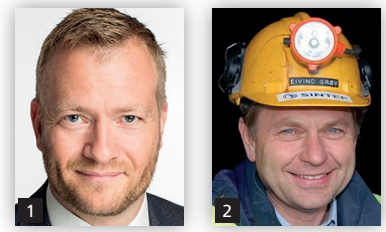

The Faroe Islands north of Scotland has a disproportionally large number of road tunnels. In addition to $44 \mathrm{~km}$ of existing tunnels, two further undersea tunnels totalling $22 \mathrm{~km}$ will be completed by 2023 . A further $30 \mathrm{~km}$ undersea crossing is planned, providing nearly $\mathbf{2} \mathrm{m}$ of tunnel for each of the 50000 inhabitants. This paper describes the country's recent, current and proposed subsea tunnelling projects. When eventually completed they will reduce journey times between the 18 major islands from up to a day to no more than a few hours' drive.

\section{Introduction}

The Faroe Islands is an archipelago of 18 mountainous islands located in the Atlantic Ocean north of Scotland and $600 \mathrm{~km}$ west

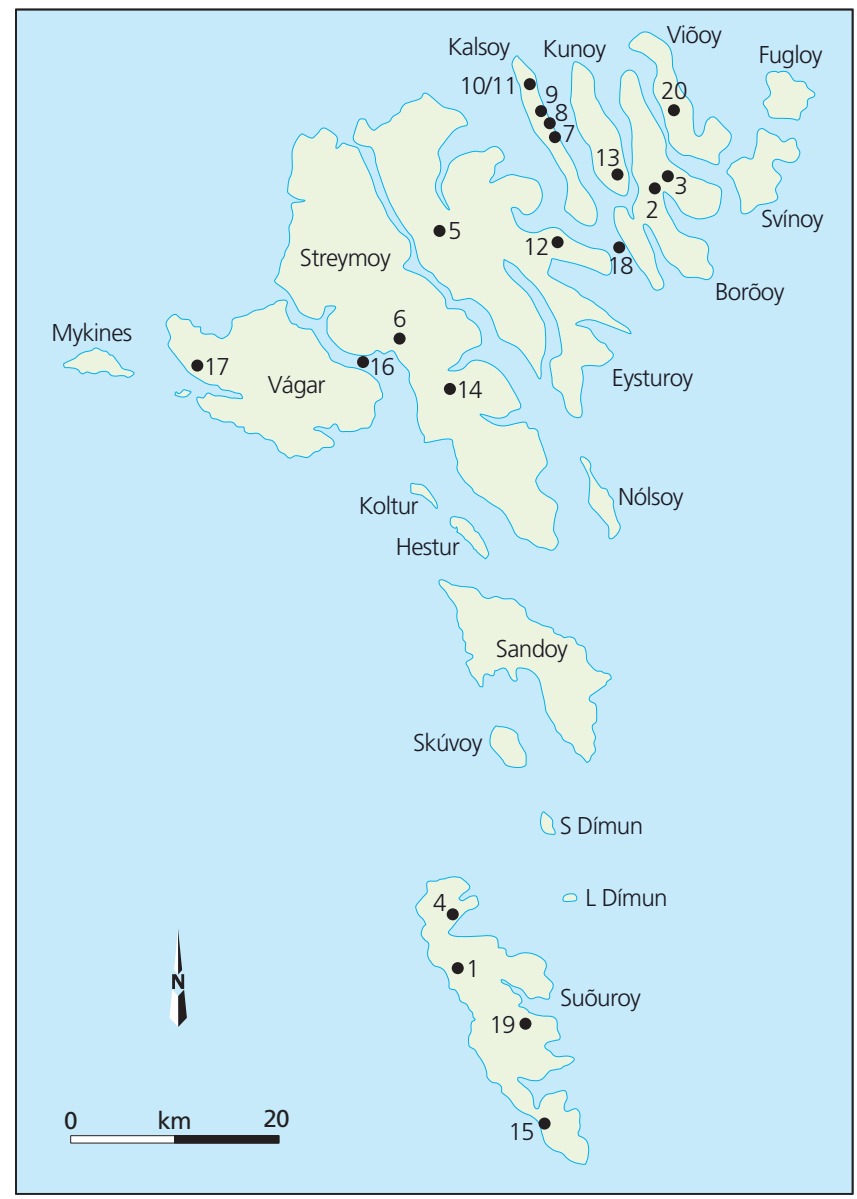

Figure 1. Location of existing Faroe Islands road tunnels (see Table 1 for details) (by Landsverk) of Norway. It is an autonomous country within the Kingdom of Denmark but is not part of the European Union.

At present there are 20 road tunnels totalling $44 \mathrm{~km}$ in operation on the islands, including two subsea toll tunnels - the $4.9 \mathrm{~km}$ long Vága tunnel that opened in 2002 and the $6.2 \mathrm{~km}$ long Norðoya tunnel that opened in 2006 (Figure 1 and Table 1).

Even before the two toll tunnels were completed and opened to traffic, various groups started looking at further underwater

Table 1. Road tunnels in operation in the Faroe Islands in 2017 (see Figure 1)

\begin{tabular}{|c|c|c|c|c|}
\hline No. on map & Tunnel & Completed & Length: m & Lanes \\
\hline 1 & Hvalbiar & 1963 & 1450 & 1 \\
\hline 2 & Árnafjarðar & 1965 & 1680 & 1 \\
\hline 3 & Hvannasund & 1967 & 2120 & 1 \\
\hline 4 & Sandvíkar & 1969 & 1500 & 1 \\
\hline 5 & Norðskála & 1976 & 2520 & 2 \\
\hline 6 & Leyna & 1977 & 760 & 2 \\
\hline 7 & Villingadal & 1979 & 1193 & 1 \\
\hline 8 & Mikladal & 1980 & 1082 & 1 \\
\hline 9 & Ritudal & 1980 & 683 & 1 \\
\hline 10 & Teymur & 1985 & 220 & 1 \\
\hline 11 & Trøllane & 1985 & 2248 & 2 \\
\hline 12 & Leirvíkar & 1985 & 2238 & 1 \\
\hline 13 & Kunoyar & 1988 & 3031 & 1 \\
\hline 14 & Kollfjarðar & 1992 & 2816 & 2 \\
\hline 15 & Sumbiar & 1997 & 3240 & 2 \\
\hline 16 & Vága & 2002 & 4900 & 2 \\
\hline 17 & Gásadal & 2005 & 1410 & 1 \\
\hline 18 & Norðoya & 2006 & 6200 & 2 \\
\hline 19 & Hov & 2007 & 2437 & 2 \\
\hline 20 & Viðareiði & 2016 & 1950 & 2 \\
\hline Total & & & 43678 & \\
\hline
\end{tabular}


projects. Landsverk, the Faroese office of public works, focused on the Sandoy tunnel, a subsea connection between the islands of Streymoy and Sandoy, while a private enterprise looked at a tunnel connection between the islands of Streymoy and Eysturoy.

In April 2014, a decade later, a parliamentary act granted a concession to a special-purpose limited company established by the Faroese government to carry out both projects (Faroese Parliament, 2014). The concession empowers the company, P/F Eystur- og Sandoyartunlar (EST), to engage consultants to carry out the design, assign contractors for the physical works, finance the remaining costs through its own loans in the international private lending market, and finally operate and maintain the tunnels until its debt is repaid.

The Eysturoy and Sandoy toll tunnels are planned to be $11.2 \mathrm{~km}$ and $10.6 \mathrm{~km}$ long, and open for traffic in 2020 and 2023. Swedish contractor NCC - which also built the Vága and Norðoya tunnels - won a DKK2.5 billion ( $£ 225$ million) tunnelling contract in November 2016 and started work in early 2017.

Despite being a small country, the Faroes is a great nation for tunnel construction. With a population of approximately 50000 people, there is now nearly $1 \mathrm{~m}$ of road tunnel for each inhabitant. With the two new long subsea tunnels in place, a future $30 \mathrm{~km}$ long tunnel to the southernmost island of Suðuroy would bring the figure to nearly $2 \mathrm{~m}$ of tunnel per capita, most likely the highest figure worldwide.
The two ongoing tunnels will increase the mobility of the inhabitants on the Faroe Islands to a new order. The future Suðuroy tunnel will, together with the other road tunnels, enable $99 \%$ of the population in the islands to travel without ferry connections, and the journey time from one tip of the country to the diametrical tip will decrease dramatically. These really are tunnels for society.

\section{Geography and geology}

The topographic characteristics of the Faroe Islands are narrow fjords, steep mountains and hills surrounded by the Atlantic Ocean. The 18 main islands can be divided into five main areas, each internally interconnected by roads, tunnels, bridges or causeways and externally linked by ferries. The subsea tunnels are gradually replacing the ferry services.

Geologically, the country is a basaltic sub-continent separated from its surrounding neighbours. The volcanic strata include approximately $3 \mathrm{~km}$ of lithologies above sea level and at least $3.5 \mathrm{~km}$ of volcanic rock below sea level (Figure 2).

The majority of tunnels in the Faroe Islands are located in the Middle Basalt formation with a few exceptions which are found in the Upper Basalt (Heinesen and Højgaard, 2016). (a)

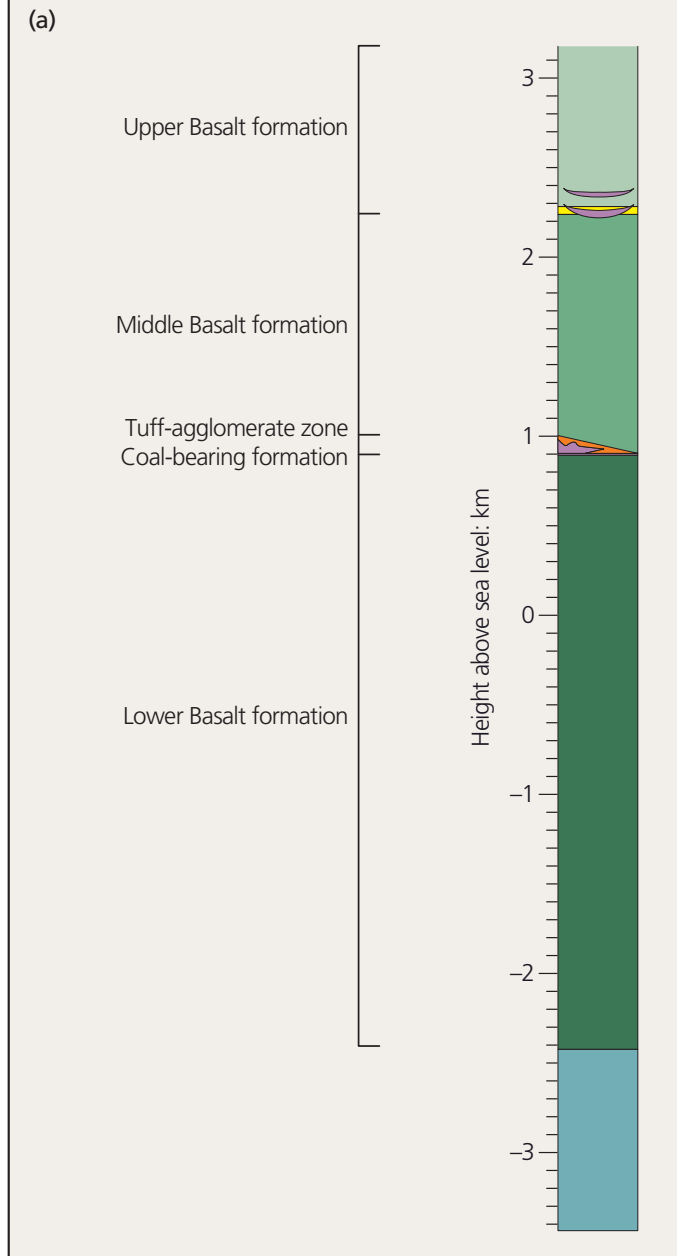

(b)

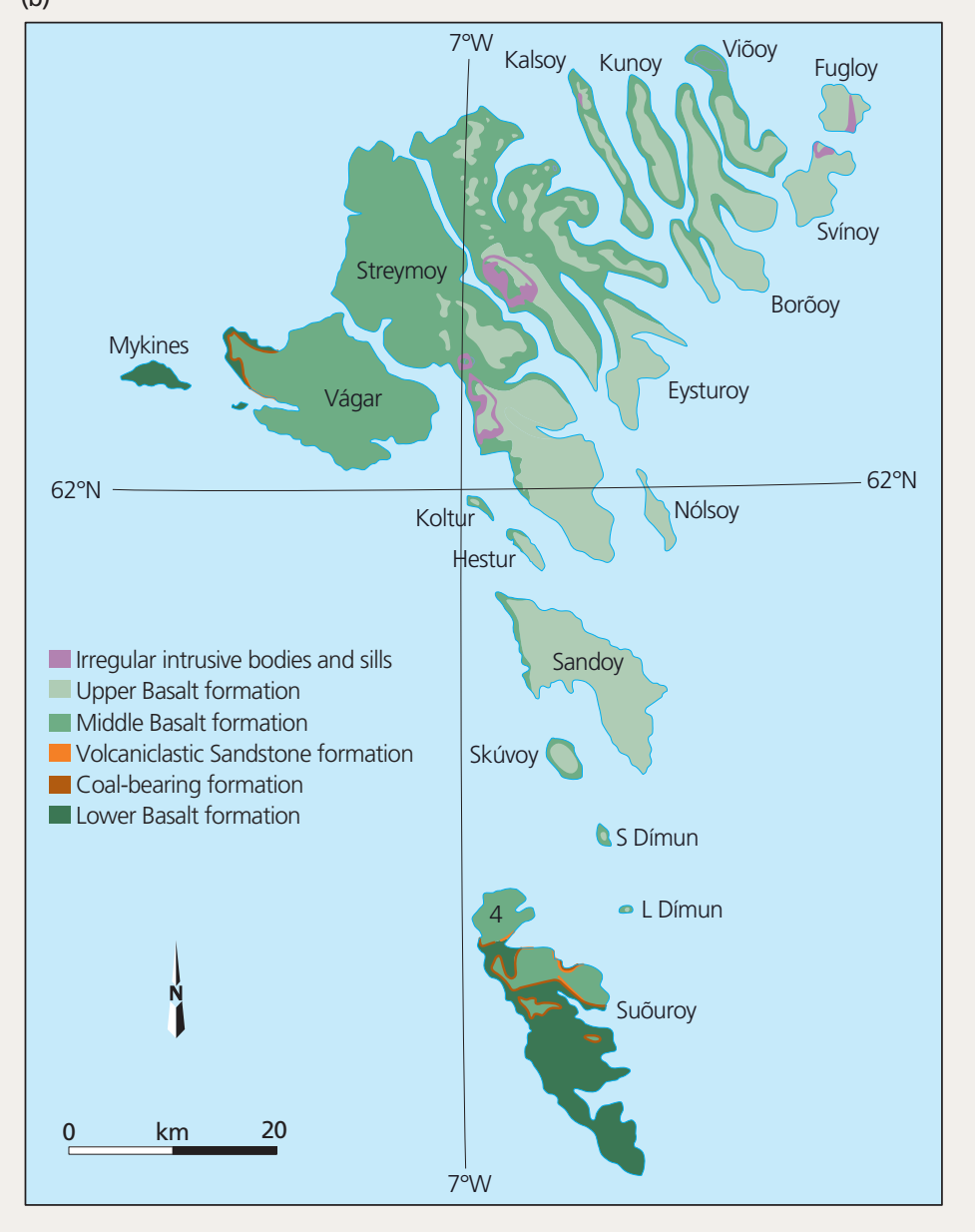

Figure 2. Typical borehole log (a) and surface geology (b) (Rasmussen and Noe-Nygaard, 1969; by Jardfeingi) 
Civil Engineering

Volume 171 Issue CE5
Subsea road tunnels in the Faroe Islands

Samuelsen and Grøv

\section{Existing tunnels}

The first road tunnel in the Faroe Islands was opened in 1963. It was built through a mountain on the southernmost island, Suðuroy, and connected two villages. The tunnelling work, which included excavation, drilling and blasting, was carried out from both sides of the mountain simultaneously.

Landsverk is the authority responsible for infrastructure on the islands, and its construction and operation of road tunnels is of great importance. In addition, some tunnels are owned and operated by private enterprises. The first of this kind were the underground caverns constructed for storage of frozen fish in Fuglafjorður, which were followed by two subsea road tunnels, the Vága and Norðoya (Grøv and Hansen, 2001, 2009) (Figure 3). The new Eysturoy and Sandoy tunnels will also be privately owned and operated under a concession.

The Faroese electricity company SEV has made substantial use of tunnels in its development projects. A total of $30 \mathrm{~km}$ of tunnels have been built, including $25 \mathrm{~km}$ at its hydropower project at Eiði on Streymoy.

\section{Tunnels under construction}

There are several reasons why the Eysturoy and Sandoy road tunnels (Figure 4) are being built. They will

- connect the Faroe Islands together to create a growth area

- improve infrastructure for $70 \%$ of the population

- reduce travel time to the capital Torshavn by $50-75 \%$

- create an alternative to existing mountain roads from the north region

- reduce travel costs by $50-75 \%$

- improve infrastructure for the fishing industry

- establish Strendur and Runavík as suburbs to Torshavn

- connect Sandoy to the 'mainland'.

The Eysturoy tunnel will be about $11 \cdot 24 \mathrm{~km}$ long and consist of a main tunnel from Hvítanes on the island of Streymoy and

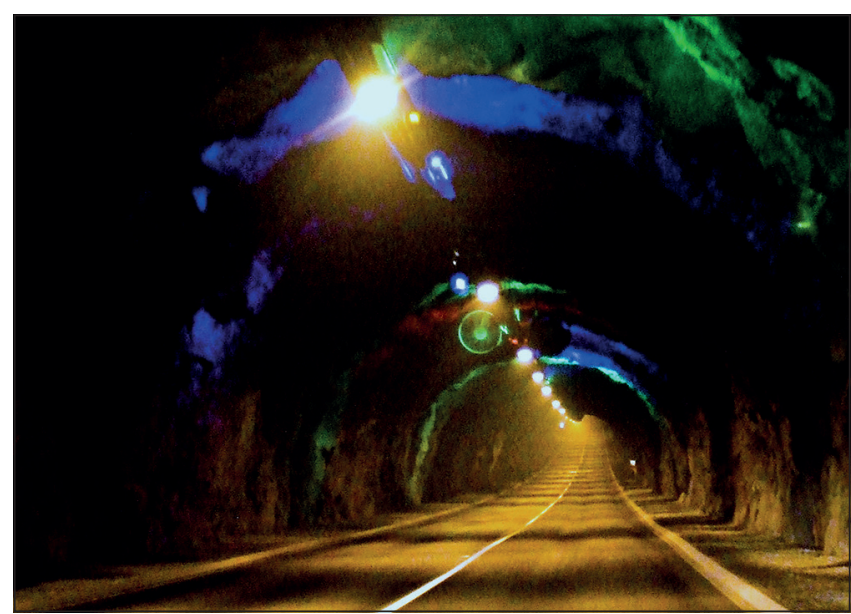

Figure 3. Norðoya tunnel was opened in 2006 (by Arne List (talk) - authors' own work, CC BY-SA 3.0, https://commons.wikimedia. org/w/index. php?curid $=4233831$ ) branch tunnels from an underground roundabout to both sides of the Skálafjord, towards Strendur in the northwest and Runavík in the northeast, respectively (Figure 5). The length of the tunnel from Hvítanes to Runavík will be about $9.7 \mathrm{~km}$, while the arm to Strendur will be approximately $1.7 \mathrm{~km}$. All three arms of the tunnel will be single-tube tunnels, and will have a maximum gradient of $5 \%$. The tunnel width will be $10 \cdot 25 \mathrm{~m}$ and the lowest point of the tunnel will be at about $187 \mathrm{~m}$ below sea level. The subsea section will be a little less than $7 \mathrm{~km}$ long (see Figures 6 and 7).

The Sandoy tunnel will be $10.8 \mathrm{~km}$ long and consist of a singletube tunnel from Gamlarætt on Streymoy to Traðadalur valley south east of Skopun on Sandoy. The tunnel will have a maximum ascending/descending gradient of $5 \%$, a width of $9.5 \mathrm{~m}$, and its lowest point will be at about $155 \mathrm{~m}$ below sea level. Its subsea section will be about $6.5 \mathrm{~km}$ long (Figure 8 ). Both tunnels are being driven using conventional drill-and-blast techniques.

The financing, construction and operation of the tunnels is being undertaken by EST, a public limited company founded and owned by the Faroese government. The company has been charged to manage an investment which, in addition to the allocation associated with the 2014 parliamentary act, will involve a debt representing $55 \%$ of the country's total borrowings. EST has gone to the international finance market to fund the construction cost.

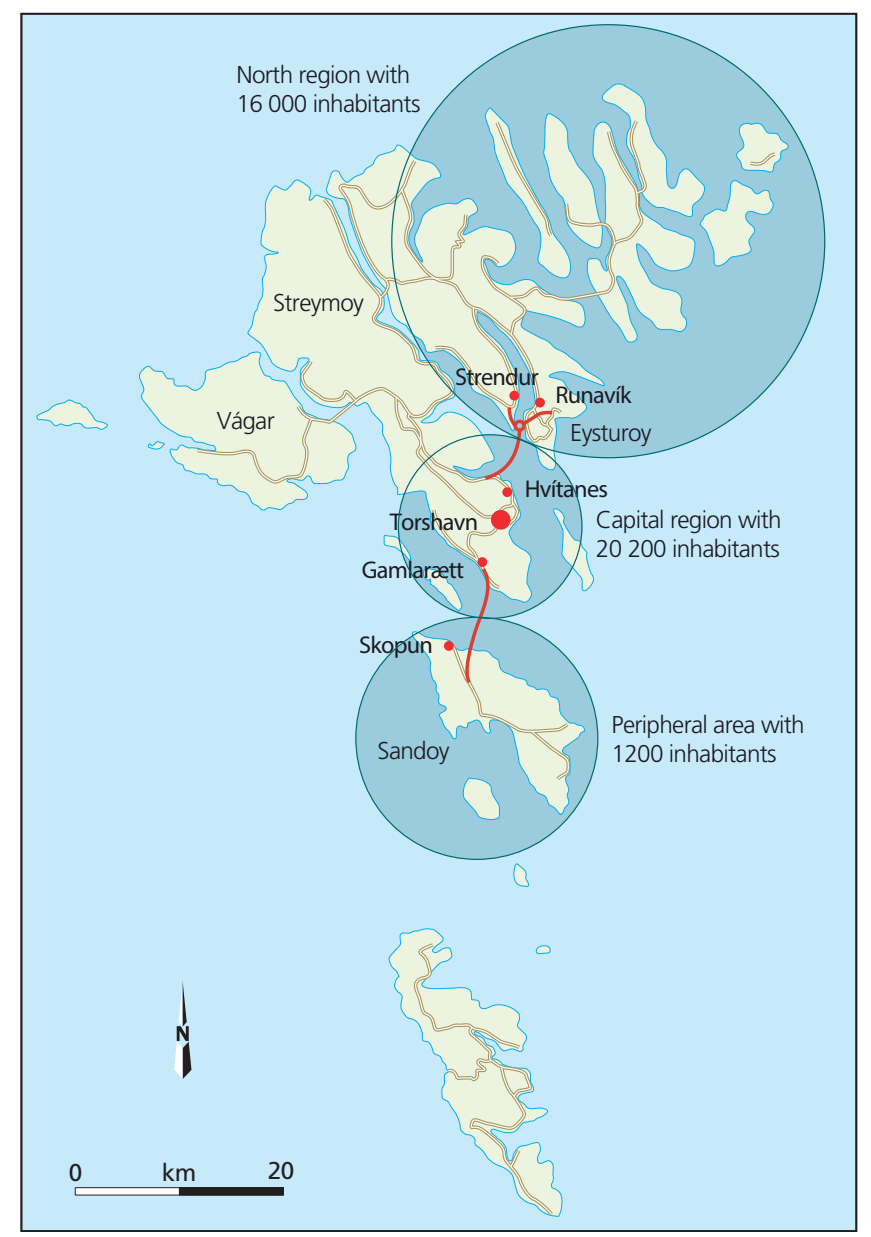

Figure 4. Location of the Eysturoy and Sandoy subsea road tunnels that are currently under construction 
Subsea road tunnels in the Faroe Islands Samuelsen and Grøv

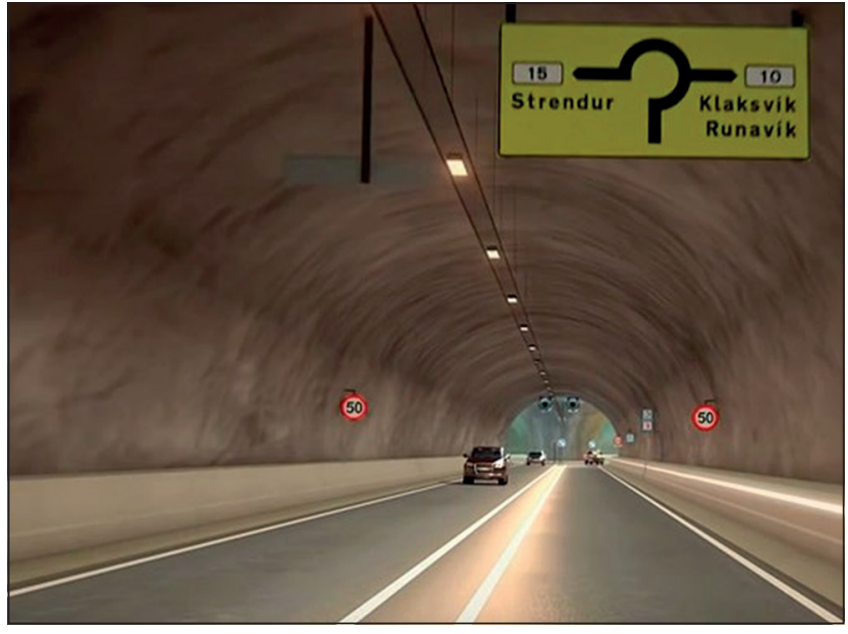

Figure 5. Computer graphic of Eysturoy tunnel, looking north towards underground roundabout

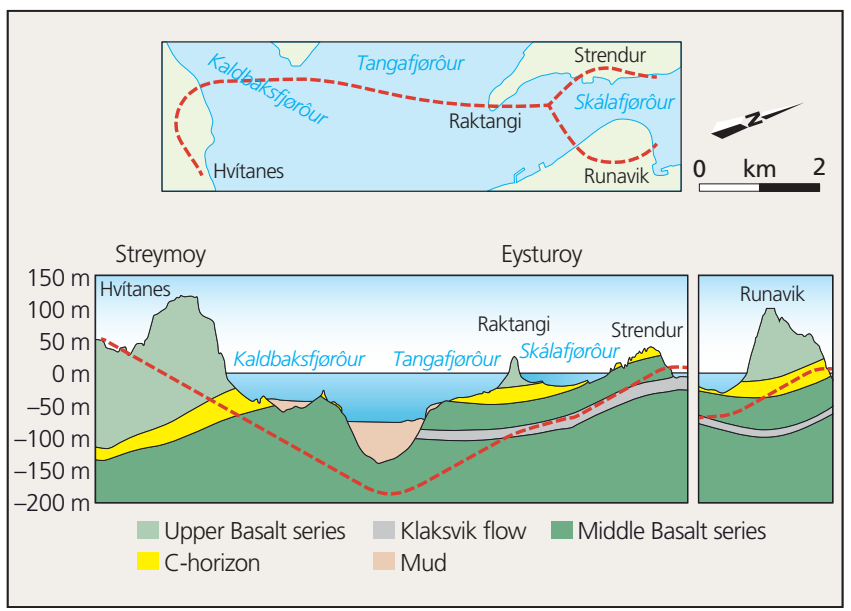

Figure 7. Plan and longitudinal section of Eysturoy tunnel (Jardfeingi)

The company was established with a share capital of DKK15 million ( $£ 1.8$ million). This was used in a preliminary phase to carry out investigations. In the next few years, the share capital in the company will be increased to DKK400 million (£48 million). The Faroese government will give this sum to the company as accumulated share capital over 10 years. The government has also undertaken to subsidise operating costs and has given the company a guarantee with respect to minimum traffic.

The pay-back time for the loans is expected to be 15 years and there are no requirements for return on capital. If income from toll collection becomes higher than expected, the toll fare will be reduced - a concept already established for the two existing toll tunnels.

The Eysturoy tunnel will be built first, where average annual daily traffic in the tunnel from Hvitanes in the south in the first years after opening in 2020 has been estimated to be 4200 vehicles. For the two branch tunnels to Strendur and Runavík in the north, the estimated average annual daily traffic in the first year is 2800 and 5500 vehicles, respectively.

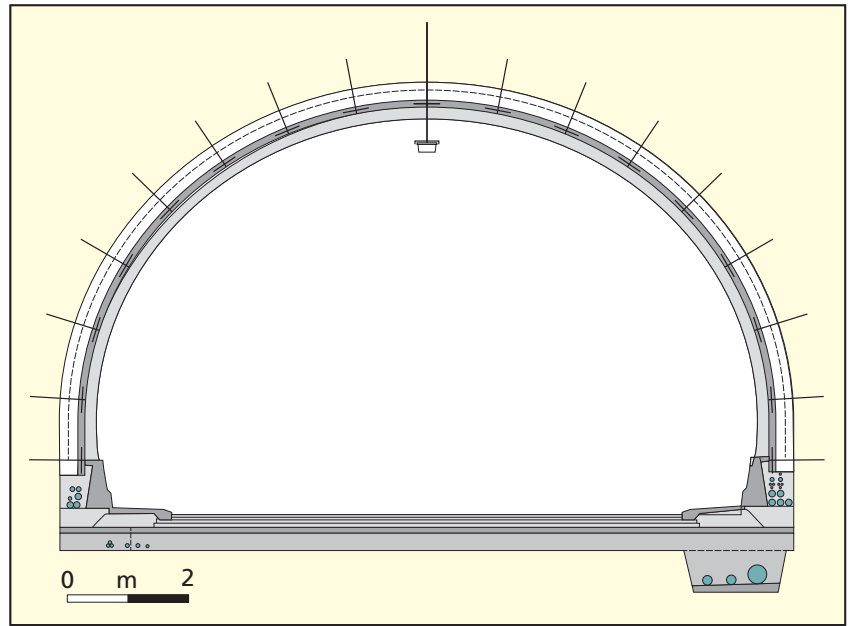

Figure 6. Typical tunnel cross-section with a self-standing inner lining (Norwegian Public Roads Administration and Norconsult)

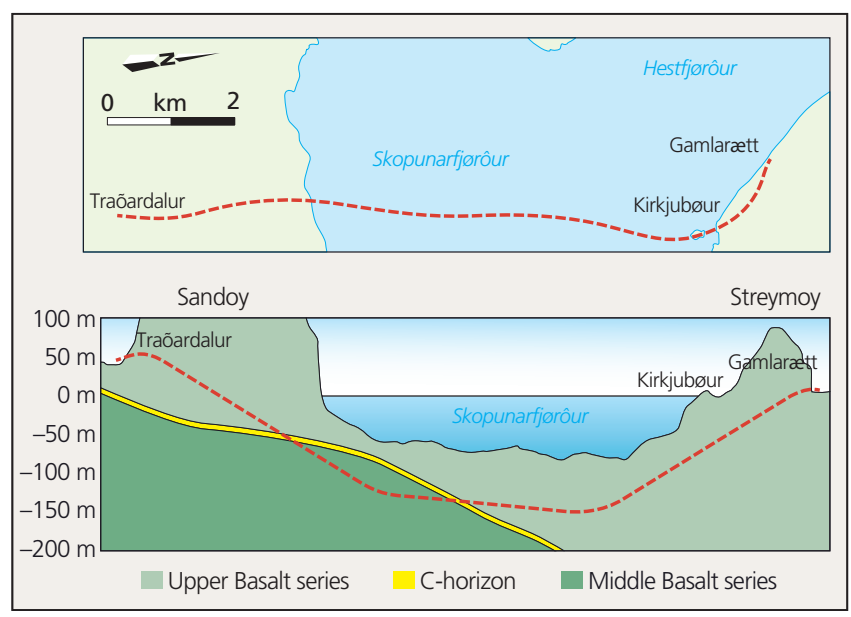

Figure 8. Plan and longitudinal section of Sandoy tunnel (Jardfeingi)

The Sandoy tunnel has a significantly lower design traffic volume, with average annual daily traffic of 310 vehicles on completion in 2023, so will be built second. The plan is that when the contractor completes the tunnelling work on the Eysturoy tunnel, all tunnelling equipment will be moved to the Sandoy tunnel to start work there while the installations works are being concluded on the Eysturoy tunnel. In this way, revenues for the owner company will be secured at an early stage.

Table 2 shows the main members of the project team.

\section{Tunnelling method}

The Norwegian Public Roads Administration (NPRA) handbook for design and construction of road tunnels (NPRA, 2011) has been used for all subsea tunnel projects in the Faroe Islands (Grøv and Hansen, 2009). All subsea tunnels in Norway have been excavated by the drill-and-blast method so this has also been adopted in the Faroes. It provides great flexibility and adaptability to varying rock conditions and is cost-effective. 
Table 2. Eysturoy and Sandoy tunnel project team

\begin{tabular}{lll}
\hline Company name & Nationality & Role \\
\hline Eystur- og Sandoyartunlar & Faroe Islands & Client \\
\hline Jardfeingi & Faroe Islands & Geological pre-investigations and data collection \\
\hline Norconsult & Norway & Design of tunnel and installation works \\
\hline Landsbyggifelagid & Faroe Islands & Design of open cuts, road works, civil works outside tunnel; site supervision \\
\hline NCC & Sweden & Construction of tunnel \\
\hline J\&K Petersen & Faroe Islands & Construction of connecting roads and open cuts \\
\hline Sintef & Norway & Technical advisor \\
\hline
\end{tabular}

The most difficult rock conditions often occur in fault zones along the deepest parts of a fjord, so any uncontrolled major water inflow would have severe consequences. Percussive probe drilling is the single most important element for safety. By applying criteria related to inflow per probe hole on when to pre-grout, the remaining inflow can be controlled and adapted to pre-set quantities for economic pumping, which is normally $2-3001 /(\operatorname{min~} \mathrm{km})$. Pre-excavation grouting is the first line of defence, so site supervision and rock mass quality assessments at the tunnel face by well-qualified engineering geologists and rock engineers are of great importance.

All rock support structures are drained, whether they are made of cast-in-place concrete linings, sprayed concrete ribs or sprayed concrete linings. Sprayed concrete is mostly applied as steel-fibrereinforced wet mix. Extensive testing demonstrates that if the thickness of the sprayed concrete is above $80 \mathrm{~mm}$ and concrete quality is at least $\mathrm{C} 45$, corrosion of steel fibres is not a problem.

The geological conditions in the Faroe Islands are well known to the tunnelling industry from numerous projects carried out over the past 30 years. However, crossing underneath fjords is inevitably associated with a higher risk and a greater uncertainty than an onshore tunnel. A typical Norwegian site investigation programme was adopted for the Faroese subsea tunnels, including

- surface mapping and studies of aerial photos and topography

- core drilling and water pressure testing in the core holes, including both straight and directionally drilled holes

- reflection seismics and bathometry

- refraction seismics.

All material gathered from the investigation, also including the client's interpretation of the factual data, was disclosed and made available in the tender documents. The contractors were also invited to examine samples from all core drillings.

Regarding minimum rock cover, NPRA's handbook states this should be $50 \mathrm{~m}$ unless competent rock mass quality can be shown. For the Eysturoy tunnel, the minimum rock cover at mid-channel - where the rock surface is about $135 \mathrm{~m}$ below sea level - was set at $42 \mathrm{~m}$, making the tunnel over $180 \mathrm{~m}$ deep. Elsewhere minimum rock cover was reduced to $30 \mathrm{~m}$.

\section{Tunnels proposed}

The next tunnel project under consideration is a subsea link between Sandoy and Suðuroy, which could be $30 \mathrm{~km}$ long depending on the choice of tunnel alignment. In 2013, several alternatives for a subsea crossing were envisaged.
However, a combination of two tunnels $17 \mathrm{~km}$ and $9 \mathrm{~km}$ long with an intermediate surfacing at the island of Skúvoy is now being advocated (Figure 9). Average annual daily traffic is likely to be 1000-1500 vehicles.

\section{Importance of tunnels in the Faroes}

With the opening of the Vága tunnel in 2002, 73\% of the Faroese population were connected through one road network. This increased to $86 \%$ when the Norðoya tunnel was opened in 2006 . By connecting the Eysturoy tunnel to the same network in 2020, the percentage of

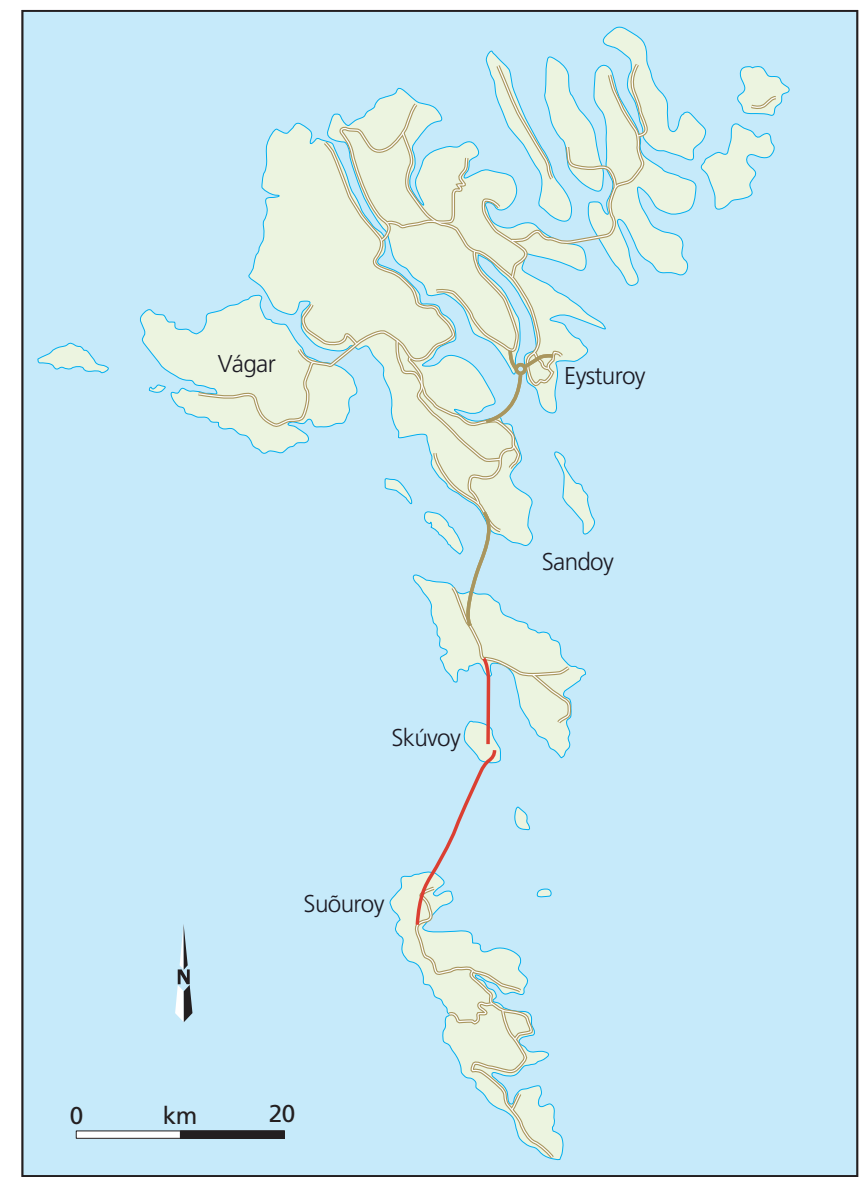

Figure 9. Location of proposed tunnels to Skúvoy and Suðuroy (Steinholm and Heinesen, 2017; by Landsverk) 
Subsea road tunnels in the Faroe Islands

Samuelsen and Grøv
Faroese linked together will remain at $86 \%$ but the travel times will decrease by at least $50 \%$ - with savings of up to 48 minutes.

The Sandoy tunnel will increase the percentage to $88 \%$, while building a tunnel to Suðuroy would put $99 \%$ of the Faroese population on the same road network (Steinhólm and Heinesen, 2017). It would be an infrastructure revolution to be able to drive ferry-free from Suðuroy to the islands in the north. What previously was a day's journey or more would be a drive of just a few hours. Table 3 highlights the travel benefits of each subsea tunnel.

Hokwerda (2017) studied the societal effects and impacts of the subsea tunnels in the Faroe Islands. He found they accelerated processes of centralisation and urbanisation, increased mobility, dissolved spatial boundaries and increased mutual dependency between villages and the capital Tórshavn.

The importance of tunnels to the country is reflected in a series of national postage stamps (Figure 10).

\section{Conclusions}

Tunnelling in the Faroe Islands is a normal and well-established way of connecting people in a land of scattered population and extensive topographical and geographical challenges. This has been the case for more than 50 years since the first road tunnel was built.

During the past 15 years the concept of crossing fjords with rock tunnels has developed and materialised into two tunnel projects, which have been in operation for over a decade. Two more subsea tunnels are now underway and will be completed by 2023 .

The ultimate project, a twin-tunnel project with a total length of almost $30 \mathrm{~km}$ from Sandoy to the southernmost island of Suðuroy is in the early stages. This project will replace the current connection, which is a ferry trip taking several hours in quite often very rough waters.

The population of the islands have great trust in their tunnels and the way that tunnels are improving their social lives, as well as the island's businesses, cutting travel times significantly. The investment per capita is significant, much larger than European infrastructure projects (Figure 11), and the tunnels are making the population in the Faroe Islands a major force in tunnelling in terms of metres of tunnel per capita.

Despite the costs, the construction time and deep crossings underneath fjords, there is a general acceptance among the Faroese public that the tunnels are important assets for the further development of their society.

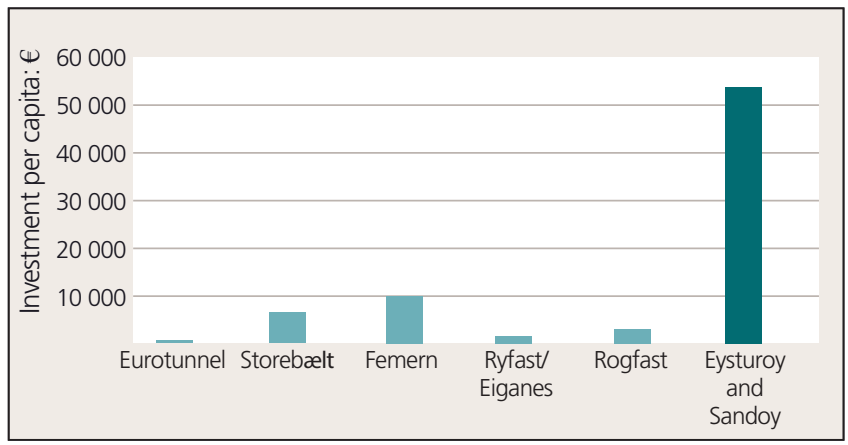

Figure 11. Comparison of Eysturoy and Sandoy per capita project cost with other European tunnels
Table 3. Impact on travel time from Torshavn to a selection of locations in the Faroe Islands after opening of tunnel connections to replace ferries or country roads

\begin{tabular}{|llcc|}
$\begin{array}{l}\text { From capital } \\
\text { Torshavn to }\end{array}$ & $\begin{array}{l}\text { Tunnel } \\
\text { name }\end{array}$ & $\begin{array}{l}\text { Travel time } \\
\text { prior to tunnel } \\
\text { opening: } \mathbf{h}\end{array}$ & $\begin{array}{l}\text { Travel time } \\
\text { after tunnel } \\
\text { opening: } \mathbf{h}\end{array}$ \\
\hline Vágar airport & Vaga & 3.0 & 1.5 \\
\hline Klaksvík & Norðoya & 2.0 & 1.0 \\
\hline Klaksvík & Eysturoy & 1.0 & 0.5 \\
\hline Skopun & Sandoy & 1.5 & 0.5 \\
\hline Suðuroy & Suðuroy & 4.0 & 1.0 \\
\hline
\end{tabular}

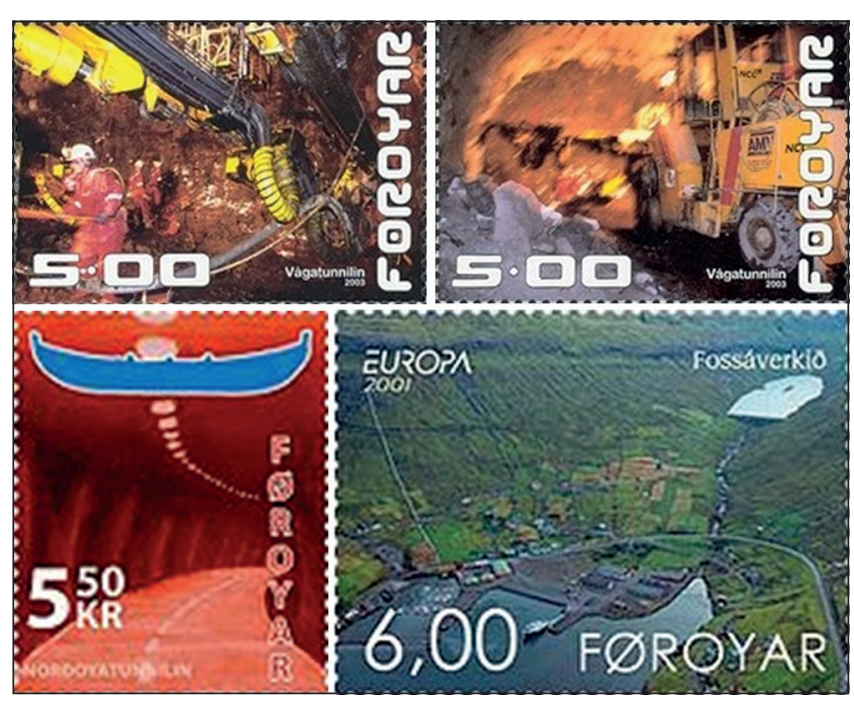

Figure 10. Tunnelling activities shown on postage stamps

\section{References}

Faroese Parliament (2014) Løgtingslóg nr. 30 frá 14 Apríl 2014 um at stovna partafelag og at byggja og reka undirsjóvartunlar millum Streymoy og Eysturoy og millum Streymoy og Sandoy, sum broytt við løgtingslóg nr. 54 frá 6. mai 2016. Faroese Parliament, Tórshavn, Faroe Islands (in Faroese).

Grøv E and Hansen DR (2001) Sub-sea tunnelling the Vestmannasund with a $30 \mathrm{~m}$ rock pillar to the Atlantic Ocean. In Strait Crossings 2001 (Krokeborg J (ed.)) CRC Press/Balkema, Lisse, the Netherlands, pp. 425-434.

Grøv E and Hansen DR (2009) 30 m rock pillar to the Atlantic Ocean, subsea tunnelling in the Faroe Islands. In Strait Crossings 2009 (Krokeborg J (ed.)). CRC Press/Balkema, Lisse, the Netherlands.

Heinesen M and Højgaard B (2016) Jarðfeingi - Geological reports. P/F Eystur- og Sandoyartunlar Tórshavn, Faroe Islands.

Hokwerda R (2017) Tunnel Visionary. The Social Effects and Impacts of Sub-sea Tunnels on the Faroe Islands. MSc Thesis, University of Groningen, Groningen, the Netherlands.

NPRA (Norwegian Public Roads Administration) (2011) Håndbok N500 (2011). NPRA, Oslo, Norway (in Norwegian).

Rasmussen J and Noe-Nygaard A (1969) Geological Map and Description of the Faroe Islands. The Danish Geological Survey (in Danish).

Steinhólm A and Heinesen F (2017) Suðuroyartunnilin, Miðnámsskúlin i Suðuroy. AB Landsverk, Sweden. 